Environmental Radioactivity

Elsevier Editorial system(tm) for Journal of

Manuscript Draft

Manuscript Number: JENVRAD-D-15-00640R1

Title: On mechanism of biological activation by tritium

Article Type: SI: ENVIRA2015

Keywords: tritium, low-dose effect, radiation hormesis, luminous marine bacteria, DNA mutations

Corresponding Author: Prof. Nadezhda S Kudryasheva, Prof.

Corresponding Author's Institution: Institute of Biophysics SB RAS

First Author: Nadezhda Kudryasheva

Order of Authors: Nadezhda Kudryasheva; Tatiana V Rozhko, PhD; Gennadii A Badun, PhD; Irina A Razzhivina; Oleg A Guseynov, PhD; Valeria E Guseynova, PhD

Abstract: The mechanism of biological activation by beta-emitting radionuclide tritium was studied. Luminous marine bacteria were used as a bioassay to monitor the biological effect of tritium with luminescence intensity as the physiological parameter tested. Two different types of tritium sources were used: HTO molecules distributed regularly in the surrounding aqueous medium, and a solid source with tritium atoms fixed on its surface (tritium-labeled films, 0.11, 0.28, 0.91, and 2.36 $\mathrm{MBq} / \mathrm{cm} 2)$. When using the tritium-labeled films, tritium penetration into the cells was prevented. The both types of tritium sources revealed similar changes in the bacterial luminescent kinetics: a delay period followed by bioluminescence activation. No monotonic dependences of bioluminescence activation efficiency on specific radioactivities of the films were found. A 15-day exposure to tritiated water (100 MBq/L) did not reveal mutations in bacterial DNA. The results obtained give preference to a "non-genomic" mechanism of bioluminescence activation by tritium. An activation of the intracellular bioluminescence process develops without penetration of tritium atoms into the cells and can be caused by intensification of trans-membrane cellular processes stimulated by ionization and radiolysis of aqueous media. 


\section{ON THE MECHANISM OF BIOLOGICAL ACTIVATION BY TRITIUM}

T.V. Rozhko ${ }^{1,2}$, G.A. Badun ${ }^{3}$, I.A. Razzhivina ${ }^{3}$, O.A. Guseynov ${ }^{2}$, V.E. Guseynova ${ }^{2}$, N.S. Kudryasheva ${ }^{2,4}$

${ }^{1}$ Krasnoyarsk State Medical Academy, P.Zheleznyaka 1, Krasnoyarsk, 660022, Russia

${ }^{2}$ Siberian Federal University, Svobodny 79, Krasnoyarsk, 660041, Russia

${ }^{3}$ Moscow State University, Department of Chemistry, Moscow, 119991, Russia

${ }^{4}$ Institute of Biophysics SB RAS, Akademgorodok 50/50, Krasnoyarsk, 660036, Russia

phone: $+7(391) 2494242$

fax: $+7(391) 2433400$

e-mail: ﹎.qdr@yahoo.com 
Effect of tritium on luminous marine bacteria is attributed to hormesis phenomenon Tritium activates bacterial luminescence without penetration into cells Bacterial DNA mutations are not responsible for activation by tritium Ionization of aqueous medium is responsible for radiation hormesis 


\section{Abstract}

The mechanism of biological activation by beta-emitting radionuclide tritium was studied. Luminous marine bacteria were used as a bioassay to monitor the biological effect of tritium with luminescence intensity as the physiological parameter tested. Two different types of tritium sources were used: HTO molecules distributed regularly in the surrounding aqueous medium, and a solid source with tritium atoms fixed on its surface (tritium-labeled films, $0.11,0.28,0.91$, and $2.36 \mathrm{MBq} / \mathrm{cm}^{2}$ ). When using the tritiumlabeled films, tritium penetration into the cells was prevented. The both types of tritium sources revealed similar changes in the bacterial luminescent kinetics: a delay period followed by bioluminescence activation. No monotonic dependences of bioluminescence activation efficiency on specific radioactivities of the films were found. A 15-day exposure to tritiated water (100 $\mathrm{MBq} / \mathrm{L}$ ) did not reveal mutations in bacterial DNA. The results obtained give preference to a "non-genomic" mechanism of bioluminescence activation by tritium. An activation of the intracellular bioluminescence process develops without penetration of tritium atoms into the cells and can be caused by intensification of trans-membrane cellular processes stimulated by ionization and radiolysis of aqueous media.

Keywords: tritium, low-dose effect, radiation hormesis, luminous marine bacteria, DNA mutations.

\section{Introduction}

Microorganisms encompass a wide range of metabolically diverse groups playing the most fundamental part in the biosphere, and their physiological indices are traditionally used to monitor environmental toxicity including radiation toxicity. Marine luminous bacteria are particularly appropriate as a tool in this kind of research since they are highly sensitive to the presence of toxic compounds. Luminescence intensity, the central physiological parameter tested, can be easily measured instrumentally. It is also beneficial that luminous bacteria-based assays are simple and not time consuming due to high rates of bioluminescence response. Therefore such assays provide large amounts of data obtained under comparable conditions which is essential for their statistical treatment. These are the reasons why luminous bacteria have been used as a toxicity bioassay for several decades (Grabert and Kossler, 1997; Roda et al., 2004; Girotti et al., 2008; Thakur and Ragavan, 2013; Esimbekova et al., 2014; Kudryasheva and Tarasova, 2015). It also explains the increasing interest and intensive research into the functions of luminous bacteria, their sensitivity to exogenous compounds (Girotti et al. 2008; Deryabin and Aleshina, 2008; Hastings, 2012), and the mechanisms of light emission (Nemtseva and Kudryasheva, 2007; Hou et al., 2014).

In the course of recent years, extensive research has been performed into the influence of ionizing radiation on bioluminescence of marine bacteria (Min et al., 2003; Rozhko et al., 2007, 2008, 2011; Alexandrova et al., 2011; Selivanova et al., 2013 , 2014). The studies of the effects of alpha- and beta-emitting radionuclides on luminous bacteria under the conditions of chronic low-dose irradiation are summarized in (Kudryasheva and Rozko, 2015). Non-linear dose-effect dependence was demonstrated in the range of activity concentrations of 1.0-6.7 kBq/L and 0.0002-200 MBq/L for americium-241 and tritium, respectively; no monotonic dependencies of bioluminescence intensity on the exposure time and activity concentrations were found. Three successive kinetic stages in solutions of americium-241 and tritium (alpha- and beta-emitting radionuclides, respectively) were demonstrated: (1) absence of effect, (2) activation, and (3) inhibition of bioluminescence. This bacterial response was interpreted in terms of the standard reaction of organisms to a stress-factor: (1) stress recognition or a "threshold" for the effect, (2) adaptive response/syndrome, and (3) suppression of the physiological function. Since the term "toxicity" is defined as suppression of biological functions of organisms, the third stage can be attributed to radiation toxicity.

Activation of vital functions is a well-known effect common to all living organisms. It is attributed to triggering cell defense response under the influence of low dose stressors, either chemical agents or radiation. The examples of this phenomenon are: nonspecific adaptive syndrome of plants (Pakhomova, 1995) and stress reaction of animals (Selye, 1980). Additionally, it is known that low doses of bioactive substances serve as effective drugs (Burlakova et al., 2004; Halliwell and Gutteridge, 2007; Calabrese and Blain, 2011).

The non-linear effects of radionuclides on luminous bacteria can be attributed to radiation hormesis phenomenon (Kaiser, 2003; Calabrese, 2013, 2014). Generally, 'hormesis' is a term for favorable biological responses to low exposures to toxins and other 
stressors with ionizing radiation involved. The hormesis mechanisms are not understood yet; and experimental studies elucidating the molecular mechanisms of radiation hormesis and radiation toxicity in bacterial cells are of high interest. There exist two models explaining the mechanism of radiation hormesis; they consider the adaptive response as related to DNA mutations or cell membrane processes (Albers, 1967; Lloyd et al., 1992; Mossman, 2001; Zaka et al., 2002; Serment-Guerrero et al, 2012; Jo et al, 2012; Rana at al., 2013; Mothersill et al, 2014).

Luminous marine bacteria are a convenient model object for studying molecular mechanisms of radiation hormesis - from primary physicochemical processes under ionization conditions in water solutions to cellular membrane processes, intracellular macromolecular transformation, and mutagenic effects. The mechanisms of ionizing radiation influence on bacterial cells might be applied to analyze the impact of radiation on higher organisms.

Tritium, a soft beta emitting radionuclide without accompanying gamma-rays, is well suited for studying adaptive responses of organisms to low-dose radiation due to low energy of its radioactive decay. The maximal energy of its beta-particles is low (18.6 $\mathrm{keV}$ ) and the maximal range of their path is short ( $\sim 2 \mu \mathrm{m}$ in water). In living cells, tritium can substitute hydrogen (protium) atoms in organic molecules. Additionally, helium-3 cation being a product of tritium radioactive decay along with a free electron is a very active particle; it can withdraw an electron from organic molecules forming the stable electron shell of the inert gas, helium, and active carbocation. Therefore tritium irradiation can cause not only an adaptive response of bacterial cells but their local damage too. In humans, beta-particles are entirely absorbed by the skin surface layers; that is why tritium is not dangerous for internal structures when applied from outside the organism. Conversely, when being an endogenous factor it can penetrate into cell organelles of internal tissues and have a direct impact on their functions.

Tritium is permanently generated by space radiation at the rate of 1200 atoms s$~^{-1} \mathrm{~m}^{-2}$ in the top layers of Earth's atmosphere. In the Earth Ocean, it is mostly found as a component of tritiated water. Until the 1950s, tritium concentration in natural waters was low - one tritium per $10^{18}$ hydrogen atoms. However, after atmospheric nuclear tests it increased 1000-fold. Since the half-life of tritium is 12.32 years, its concentration eventually decreased, though local rise of tritium content developed around nuclear power plants. Local nuclear incidents increase tritium concentration dramatically as tritium is a by-product of a large number of radiochemical reactions. In the future, controlled fusion reactors can pose an additional threat of tritium contamination. This is why the issues of radioactive contamination by tritium and biological effects of beta-irradiation are of particular concern.

The current research is aimed at determining a primary mechanism of bacterial bioluminescence activation by tritium. Bioluminescence activations were compared in two experiments providing different ability of tritium to penetrate into bacterial cells. It is approached by using either tritiated water (HTO) or an aqueous medium with tritium labeled solids as an external radiation source. Involvement of DNA in radiation hormesis is estimated by comparing gene sequences in control specimens of luminous bacteria and specimens exposed to radiation. This is enabled by using contemporary methods of genetic analysis such as restriction fragment length polymorphism (Ciantar et al., 2005; Bourque et al., 2015).

The study of bioluminescence kinetics of marine bacteria exposed to (a) HTO and (b) tritium labeled films is presented in section 3.1. The results of experiments on revealing mutations in the DNA of bacteria exposed to HTO are described in section 3.2. Based on the results, two possible hormesis mechanisms responsible for the activation process in bacterial cells exposed to tritium are considered - DNA mutations and cell membrane processes - and a conclusion about the dominating mechanism is made.

The results of this study might also be considered with respect to the novel approach based on "exposome" concept complementing the genome. The "exposome" encompasses the totality of environmental (i.e. non-genetic) exposures (Rappaport and Smith, 2010; Wild, 2012). Though this term was initially introduced for human exposures, the study of simple model organisms might provide fundamental physicochemical, molecular, biochemical, and cellular bases for human exposure science.

\section{Materials and methods}

Bioluminescence intensity was measured using Microbiotest 677F based on lyophilized Photobacterium phosphoreum 1883 IBSO (Kuznetsov et al., 1996) obtained from the Institute of Biophysics SB RAS, Krasnoyarsk, Russia.

HTO (radiochemical purity 98\%) was applied as a source of ionizing radiation in bioluminescence measurements. 
Tritium was introduced in polyethylene films by the tritium thermal activation method (Badun et al., 2012). After tritium labeling, the films were purified from hydrophobic radioactive impurities in acetone. Then they were purified from labile tritium by keeping in distilled water for two weeks so that constant radioactivity was achieved. The uniformity of tritium distribution on the films was controlled by digital autoradiography with the Cyclone Plus device using OptiQuant software. Radioactivity of the films remained unchanged after a two-week period of incubation in water which ensures that tritium does not move to the aqueous bacteria suspension in the course of the experiments.

Bacterial bioluminescence kinetics was registered for $52 \mathrm{~h}$ in radioactive and nonradioactive (control) samples in $1 \mathrm{~mL} 1.5 \%$ $\mathrm{NaCl}$ solution. Radioactive samples included HTO $(2.3,9.5$, and $95.5 \mathrm{MBq} / \mathrm{L})$ or tritium-labeled polyethylene films $\left(1.5 \mathrm{x} 0.5 \mathrm{~cm}^{2}\right)$ with specific radioactivities $0.11,0.28,0.91$ and $2.36 \mathrm{MBq} / \mathrm{cm}^{2}$. The samples were kept at $4^{\circ} \mathrm{C}$, and incubated for $5 \mathrm{~min}$ at room temperature $\left(20^{\circ} \mathrm{C}\right)$ before the measurements. The conditions of bioluminescence measurements excluded the bacteria growth.

“TriStar Multimode Microplate Reader LB 941” (Berthold Technologies, Germany) was applied to measure bioluminescence intensity of radioactive $\left(I_{\text {rad }}\right)$ and control $\left(I_{\text {contr }}\right)$ test samples.

The examples of bioluminescence kinetic curves in a control solution and in HTO are presented in Fig.1.

Relative bioluminescence intensity $\boldsymbol{I}^{\text {rel }}$ was calculated as:

$I^{r e l}=\frac{I_{\text {rad }}}{I_{\text {contr }}}$,

Here, $I_{\text {rad }}$ and $I_{\text {contr }}$ are bacterial bioluminescent intensities in radioactive and control suspensions, respectively.

Values of $I^{\text {rel }}$ were plotted vs. time of exposure to tritium.

The study of mutagenic activity of HTO was performed using luminous bacteria P. phosphoreum, strain 1883 IBSO (CCIBSO 863), from the collection of the Institute of Biophysics SB RAS. The nutrient medium used for bacterial growth contained $1 \mathrm{~L} \mathrm{H}_{2} \mathrm{O}, 30 \mathrm{~g} \mathrm{NaCl}, 1 \mathrm{~g} \mathrm{KH} \mathrm{PO}_{4} \cdot 12 \mathrm{H}_{2} \mathrm{O}, 0.5 \mathrm{~g}\left(\mathrm{NH}_{4}\right)_{2} \mathrm{HPO}_{4}, 0.2 \mathrm{~g} \mathrm{MgSO} \cdot 7 \mathrm{H}_{2} \mathrm{O}, 6 \mathrm{~g} \mathrm{Na} \mathrm{HPO}_{4}, 3 \mathrm{ml}$ glycerol, and $5 \mathrm{~g}$ peptone. Optical density of bacterial suspensions was registered using KFK-2MP colorimeter, Russia. Intact bacteria were grown for 15 days in $30 \mathrm{~mL}$ nutrient medium in the absence (control) and presence of HTO, $100 \mathrm{MBq} / \mathrm{L}$.

Genetic changes were analyzed in amplicons of $16 \mathrm{~S}$ ribosomal RNA gene using the restriction fragment length polymorphism (FRLP) method as described (Ibrahim et al., 1996). DNA extraction from bacteria was carried out using AxyPrep Bacterial Genomic DNA Miniprep Kit. PCR amplification with the primers 500L (cgtgccagcagccgcggtaa) and 1350R (gacgggcggtgtgtacaag) was performed by standard procedures (Ciantar et al., 2005). PCR products were purified using the QIAGEN purification kit. Amplicons of about 900 base pairs were digested by endonucleases BspFN I, BstMB I, BstHH I, Hae III, Msp I, Rsa I, Tag I, Sse9 I. The restriction fragments obtained were separated by electrophoresis on a $1.7 \%$ agarose gel at $85 \mathrm{~V}$ using 100bp (Sibenzyme) as the molecular weight marker. Electrophoretogramms were analyzed using Gel Doc XR gel documentation system (Bio-Rad).

\section{Results}

\subsection{The effect of tritium on bioluminescence of marine bacteria}

Bioluminescence kinetics was compared in two types of experiments: in HTO and in an aqueous medium in the presence of tritium-labeled films.

As can be seen in Fig. 2, the bioluminescence kinetic curve in HTO includes two stages which are a threshold effect and activation. Hence, the response of luminous bacteria to HTO exposure is not linear; monotonic dependencies of bioluminescence intensity on exposure time were not found. This result is in accordance with nonlinear dose-effect relationship under low-dose irradiation; it can be interpreted in terms of hormesis phenomenon as mentioned in Introduction section.

The doses delivered to bacterial biomass after the first and second stages of exposure to HTO (2.3 MBq/L) (Figs 1 and 2) were estimated as 0.15 and $0.42 \mathrm{mGy}$, respectively. These values are much lower than a tentative limit of a low-dose interval, 0.2 Gy 
(Burlakova et al., 2004). Hence, two stages in the bioluminescence kinetic curve in HTO (threshold effect and bioluminescence activation, Figs 1 and 2) might be attributed to low-dose effects of the radionuclide on marine bacteria.

Earlier, the low-dose conditions were provided in experiments with luminous marine bacteria in the solutions of alpha(Rozhko at al., 2007; 2008; 2011) and beta- (Selivanova et al., 2013) emitting radionuclides; three bioluminescence kinetics stages (threshold effect, activation and inhibition) were observed there. Probably, a lower life-time of the bacteria under the conditions of the current experiment prevented from observation of the third (inhibition) stage.

As can be seen in Fig.2, the maximal $I^{\text {rel }}$ value in HTO was 2.1. Bioluminescence kinetics did not show the dependency of $I^{\text {rel }}$ on HTO activity concentration. This result is supported by our previous studies: in (Selivanova et al., 2013), no monotonic dependences of bacterial bioluminescence intensity on HTO activity concentration were found at all the times of exposure in the range of $0.2-200 \mathrm{MBq} / \mathrm{L}$.

The bacterial bioluminescence kinetic curves in HTO were compared to those in the presence of tritium-labeled films used as external radiation sources. The latter conditions prevented penetration of tritium into bacterial cells. The time-course of relative bioluminescent intensity is presented in Fig. 2 with $0.11 \mathrm{MBq} / \mathrm{cm}^{2}$ film radioactivity as an example. More effective activation (as compared to HTO) is evident from this Figure: the maximal value of $I^{\text {rel }}$ was 6.1. No dependency of the bioluminescence activation efficiency on the specific radioactivity of the films was found, similar to the results with HTO. The delay for bioluminescent activation was $21 \mathrm{~h}$ for the film radioactivitiy $0.11 \mathrm{MBq} / \mathrm{cm}^{2}$. The films of all specific radioactivities showed higher delays than those in HTO.

Hence, two types of exposures to tritium in aqueous solutions were applied: bacterial cells were exposed to HTO and to tritium fixed on a solid cover (tritium-labeled polyethylene films). In the latter case, penetration of tritium to the bacterial cells was excluded. Both types of experiments revealed bioluminescence activation; the activation efficiency was higher and the delays were longer for tritium labeled films.

Probably, the tritium effects result from ionization of aqueous media followed by intensification of cellular membrane processes. Hydrated electrons and reactive oxygen species can be considered as biologically active particles in aerated water media.

To study the details of tritium effect on luminous marine bacteria, mutagenic activity of HTO was evaluated and described in section 3.2

\subsection{Testing of mutagenic effect of HTO}

The DNA of marine bacteria exposed to $100 \mathrm{MBq} / \mathrm{L}$ HTO for 15 days was examined using 16S rRNA PCR-RFLP analysis. To find out whether the dose accumulated by bacteria (about $0.1 \mathrm{~Gy}$ ) lead to any genetic mutations, the marker sequence of $16 \mathrm{~S}$ rRNA gene was amplified and subjected to restriction enzyme digest. Using this procedure, genetic differences might be revealed due to different lengths of the restriction fragments obtained.

The patterns of restriction fragments distribution in 16S rRNA PCR-RFLP analysis of P. phosphoreum with restriction endonuclease Sse9 I are shown in Fig.3, where three replicates exposed to HTO are compared with the control (P.phosphoreum without tritium treatment). The identical patterns for lanes 2, 3, 4, 5 and 6 (fragments of about 410, 240, 120 and 50 base pairs) indicate that no changes have occurred in endonuclease $S s e 9$ I restriction sites.

For validation of the method, the distribution of restriction fragments for a corresponding amplicon of Ralstonia eutropha B5786 was examined, which is represented with lane 1 in Fig.3. A different position of the restriction fragments compared to $P$. phosphoreum reflects the genetic differences between these two species which confirms that the method itself is sensitive enough.

Performing 16S rRNA RFLP analysis with the other seven endonucleases (BspFN I, BstMB I, BstHH I, Hae III, Msp I, Rsa I, Tag I) did not show any differences between gene sequences of the control and exposed to tritium $P$. phosphoreum. Thus, it can be concluded that under the tested conditions of bacteria tritium treatment no genetic mutations occurred in the sites of all the eight endonucleases used. 


\section{Conclusions}

This paper presents the study of the mechanism of the tritium activation effect. Luminous marine bacteria are used as the simplest biological tool for these investigations. The study provides comparison between biological effects of tritium from two different types of sources - HTO molecules distributed regularly in an aqueous medium, and a solid source with tritium atoms fixed on its surface (tritium-labeled films). The second type of irradiation prevented tritium penetration into the cells.

The both types of tritium irradiation revealed similar changes in the bacterial emission: the delay period followed by the bioluminescence activation. However, the delay periods were longer and the activation efficiencies were higher for the solid tritium source. No monotonic dependences of the bioluminescence kinetic parameters on specific radioactivities were found. The absence of monotonic dependencies on exposure time and specific radioactivities/activity concentrations attributes the effects of tritium to the radiation hormesis phenomenon.

The 15-day exposure to tritiated water (100 MBq/L) did not reveal any mutations in the bacterial DNA.

Based on the results, a conclusion was made that a "non-genomic" mechanism of bioluminescence activation by tritium is dominating. Probably, the tritium effects result from ionization of aqueous media followed by intensification of cellular membrane processes. Hydrated electrons and reactive oxygen species can be considered as biologically active particles in aerated water solutions.

\section{Acknowledgements}

Authors are thankful to P. Karpenok and I. Litvinova for experimental support. The work was supported by the Russian Foundation for Basic Research, Grant No.13-04-01305a; the branch of the state budget allocated to the fundamental research at the Russian Academy of Sciences (project No 01201351504); Krasnoyarsk Regional Foundation.

\section{REFERENCES}

Albers, R.W., 1967. Biochemical aspects of active transport. Biochemistry 36, 727-756.

Alexandrova, M., Rozhko, T., Vydryakova, G., Kudryasheva, N., 2011. Effect of americium-241 on luminous bacteria. Role of Peroxides. J. Environ. Radioact. 102, 407-411.

Badun, G.A., Chernysheva, M.G., Ksenofontov A.L., 2012. Increase in the specific radioactivity of tritium-labeled compounds obtained by tritium thermal activation method. Radiochimica Acta 100, 401-408. doi: 10.1524/ract.2012.1926

Bourque, A.S., Vega-Thurber, R., Fourqurean, J.W., 2015. Microbial community structure and dynamics in restored subtropical seagrass sediments. Aquat. Microb. Ecol. 74, 43-57.

Burlakova, E.B., Konradov, A.A., Maltseva, E.X., 2004. Effect of extremely weak chemical and physical stimuli on biological systems. Biophysics (Moscow) 49, 522-534.

Calabrese, E.J, 2014. Hormesis: a fundamental concept in biology. Microbial Cell 1, 145-149.

Calabrese, E.J., 2013. Hormetic mechanisms. Crit. Rev. Toxicol. 43, 580-606.

Calabrese, E.J., Blain, R.B., 2011. The hormesis database: The occurrence of hormetic dose responses in the toxicological literature. Reg. Toxicol. Pharmacol. 61, 73-81.

Deryabin, D.G., Aleshina, E.S., 2008. Natural and recombinant luminescent microorganisms in biotoxicity testing of mineral waters. Appl. Biochem. Microbiol. 44, 378-381.

Esimbekova, E., Kratasyuk, V., Shimomura, O., 2014. Application of enzyme bioluminescence in ecology. Adv. Biochem. Eng. Biotechnol. 144, 67-109. http://dx.doi.org/10.1007/978-3-662-43385-0_3.

Ciantar, M., Newman, H.N., Wilson, M., Spratt, D. A., 2005. Molecular identification of Capnocytophaga spp. via 16S rRNA PCRrestriction fragment length polymorphism analysis. J. Clin. Microbiol. 43, 1894-1901.

Girott,i S., Ferri, E., Fumo, M., Maiolini, E., 2008. Monitoring of environmental pollutants by bioluminescent bacteria. Anal. Chim. Acta 608, 2-21. 
Grabert, E., Kossler F., 1997. About the effects of nutrients on the luminescent bacteria test. In: Bioluminescence and Chemiluminescence, ed. Hastings JW, Kricka LJ, Stanley PE, Chichester:John Wiley \& Sons, 291-294.

Halliwell, B., Gutteridge, J.M.C., Free radicals in biology and medicine. 2007. New York: Oxford University Press, pp. 704.

Hastings, J.W., 2012. Bioluminescence. Chapter 52 in Cell Physiology Sourcebook. Elsevier. 925-947.

Hou, C., Liu, Y.J., Ferré, N., Fang, W.H., 2014. Understanding bacterial bioluminescence: A theoretical study of the entire process, from reduced flavin to light emission. Chemistry-A European Journal 20, 7979-7986.

Jo, E.R., Jung, P.M., Choi, J., Lee. J.W., 2012. Radiation sensitivity of bacteria and virus in porcine xenoskin for dressing agent. Radiat. Phys. Chem. 81, 1259-1262.

Min, V.J., Lee, C.W., Gu, M.B., 2003. Gamma-radiation dose-rate effects on DNA damage and toxicity in bacterial cells. Radiat. Environ. Bioph. 42, 189-192.

Kaiser, J., 2003. Hormesis: sipping from a poisoned chalice. Science 302, 376-379.

Kudryasheva, N.S., Tarasova, A.S., 2015. Pollutant toxicity and detoxification by humic substances: mechanisms and quantitative assessment via luminescent biomonitoring. Environ. Sci. Pollut. Res. 22, 155-167. DOI: 10.1007/s11356-014-3459-6.

Kudryasheva, N.S. Rozhko, T.V., 2015. Effect of low-dose ionizing radiation on luminous marine bacteria: radiation hormesis and toxicity. J. Environ. Radioact. 142 68-77.

Kudryasheva, N.S., 2006. Bioluminescence and exogenous compounds. Physico-chemical basis for bioluminescent assay. J. Photochem. Photobiol. B 83, 77-86.

Kuznetsov, A.M., Rodicheva, E.K., Shilova, E.V., 1996. Bioassay based on lyophilized bacteria. Biotekhnologiya 9, 57-61 (in Russian).

Lloyd, D.C., Edvards, A.A., Leonard, A,, Deknut, G.L., Verschaeve, L., Natarajan, A.T., Darrudi, F., Obe, G., Palitti, F., Tanzarella, A., Tawn, E.J., 1992. Chromosomal aberrations in human lymphocytes induced in vitro by very low doses of X-rays. Int. J. Radiat. Biol. 61, 335-343.

Mossman, J.L., 2001. Deconstructing radiation hormesis. Health Physics 80, 263-269.

Mothersill, C., Seymour, C., 2014. Implications for human and environmental health of low doses of ionising radiation. J. Environ. Radioact, 133, 5-9.

Nemtseva, E.V., Kudryasheva, N.S., 2007. The mechanism of electronic excitation in bacterial bioluminescent reaction. Uspekhi Khimii 76, 101-112.

Pakhomova, V.M., 1995. The main provisions of the modern theory of stress and nonspecific adaptation syndrome in plants. Tsytologya 37, 66-91.

Rana, D., Matsuura, T., Kassim, M.A., Ismail, A.F., 2013. Radioactive decontamination of water by membrane processes. Desalination 321, 77-92.

Rappaport, S.M., Smith, M.T., 2010. Epidemiology. Environment and disease risks. Science 330 (6003): $460-461$. doi:10.1126/science.1192603.

Roda, A., Pasini, P., Mirasoni, M., Michchelini, E., Guardigli, M., 2004. Biotechnological application of bioluminescence and chemiluminescence. Trends Biotechnol. 22, 295-303.

Rozhko, T.V., Kudryasheva, N.S., Kuznetsov, A.M., Vydryakova, G.A., Bondareva, L.G., Bolsunovsky A.Y., 2007. Effect of lowlevel $\alpha$-radiation on bioluminescent assay systems of various complexity. Photochem. Photobiol. Sci. 6, 67-70.

Rozhko, T.V., Kudryasheva, N.S., Aleksandrova, M.A., Bondareva, L.G., Bolsunovsky, A.Y., Vydryakova, G.V., 2008. Comparison of effects of uranium and americium on bioluminescent bacteria. J. Sib. Fed. Univ. Biol. 1, 60-64.

Rozhko, T.V., Bondareva, L.G., Mogilnaya, O.A., Vydryakova, G.A., Bolsunovsky, A.Y., Stom, D.I., Kudryasheva, N.S., 2011. Detoxification of Am-241 solutions by humic substances: bioluminescent monitoring. Anal. Bioanal. Chem. 400, $329-333$.

Selivanova, M.A., Mogilnaya, O.A., Badun, G.A., Vydryakova, G.A., Kuznetsov, A.M., Kudryasheva, N,S., 2013. Effect of tritium on luminous marine bacteria and enzyme reactions. J. Environ. Radioact. 120, 19-25.

Selivanova, M.A., Rozhko, T.V., Devyatlovskaya, A.S., Kudryasheva, N.S.. 2014. Comparison of chronic low-dose effects of alphaand beta-emitting radionuclides on marine bacteria. Cent. Eur. J. Biol. 9, 951-959. 
Selye, H., 1980. Changing distress into eustress: Hans Selye voices theories on stress. Tex. Med. 76, 78-80.

Serment-Guerrero, J., Breña-Valle, M., Aguilar-Moreno, M., Balcázar, M., 2012. Evidence of DNA double strand breaks formation in Escherichia coli bacteria exposed to alpha particles of different LET assessed by the SOS response. Appl. Radiat. Isot. 71, 66-70.

Thakur, M.S., Ragavan, K.V., 2013. Biosensors in food processing. J. Food Sci. Technol. 50, 625-641.

Wild, C.P., 2012. The exposome: from concept to utility. Int. J. Epidemiol. 41, 24-32. doi:10.1093/ije/dyr236. PMID 22296988.

Zaka, R., Chenal, C., Misset, M.T., 2002. Study of external low irradiation dose effects on induction of chromosome aberrations in Pisum sativum root tip meristem. Mutat. Res. 517, 87-99. 


\section{Figure captions}

Fig.1. Bioluminescence intensity (I) of marine bacteria P.phosphoreum vs. time for control bacterial suspension and in HTO, 2.3 $\mathrm{MBq} / \mathrm{L}$.

Fig.2. Relative bioluminescence intensity $\left(I^{\text {rel }}\right)$ of marine bacteria P.phosphoreum vs. time of exposure to HTO, $2.3 \mathrm{MBq} / \mathrm{L}$, and to tritium-labeled polyethylene film (T-film), $0.11 \mathrm{MBq} / \mathrm{cm}^{2}$.

Fig.3. Electrophoretic diagram for 16S rRNA PCR-RFLP analysis of P. phosphoreum 1883 IBSO with restriction endonuclease Sse9

I. P. phosphoreum, control - lanes 2 and 6; P. phosphoreum, HTO - lanes 3, 4, 5; molecular weight markers 100 bp - lane M; R. eutropha B-5786 - lane 1. 


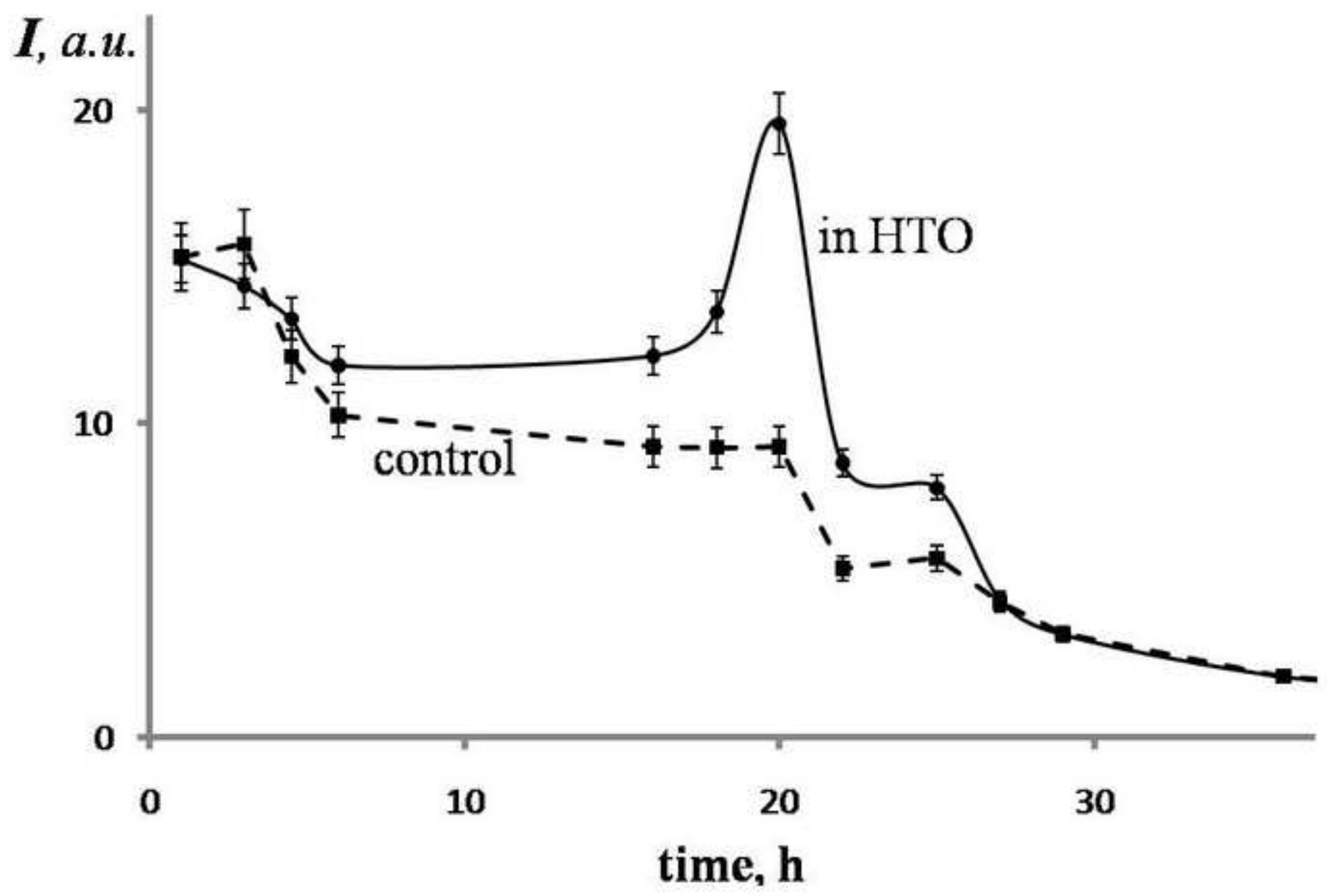




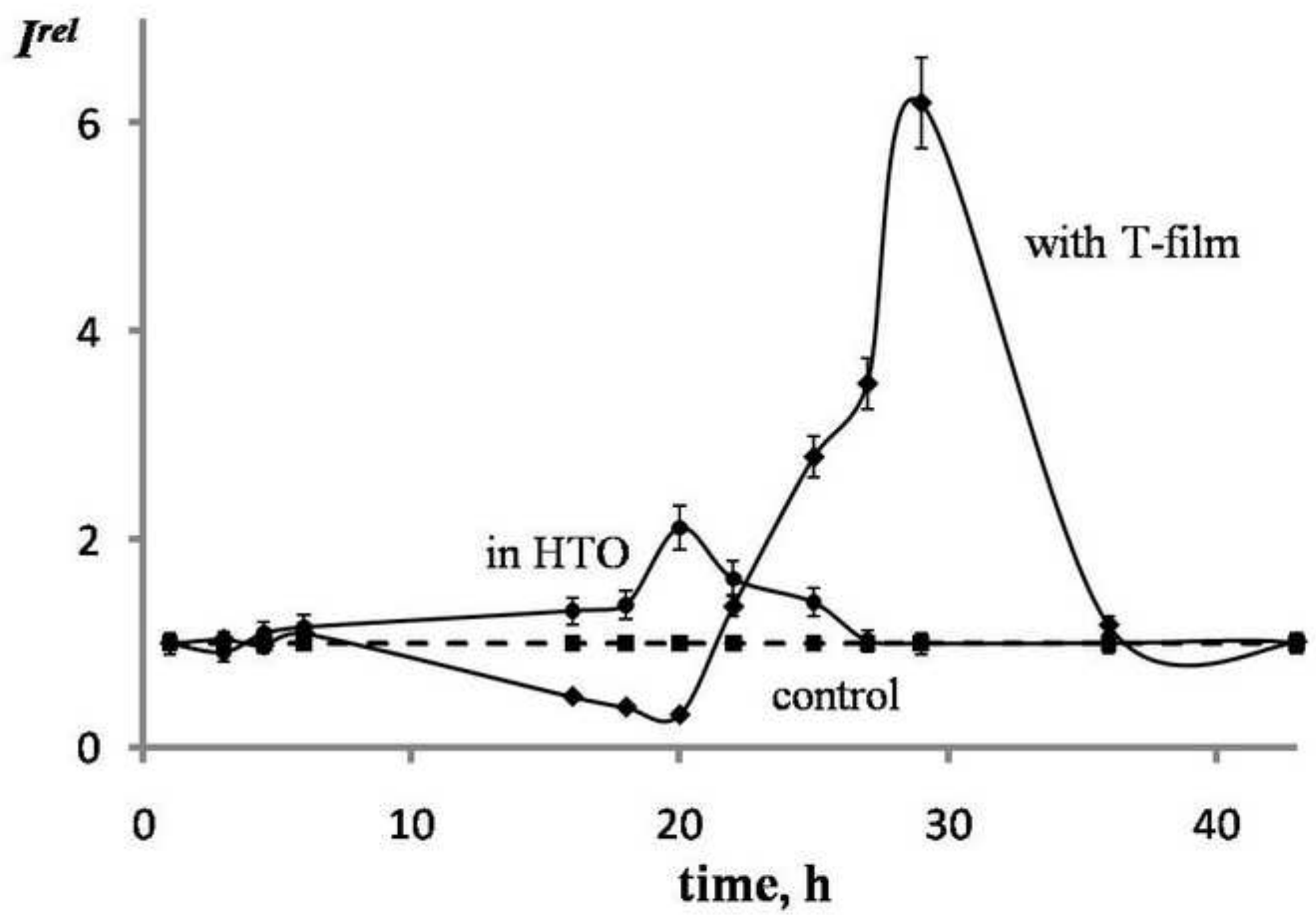


Click here to download high resolution image

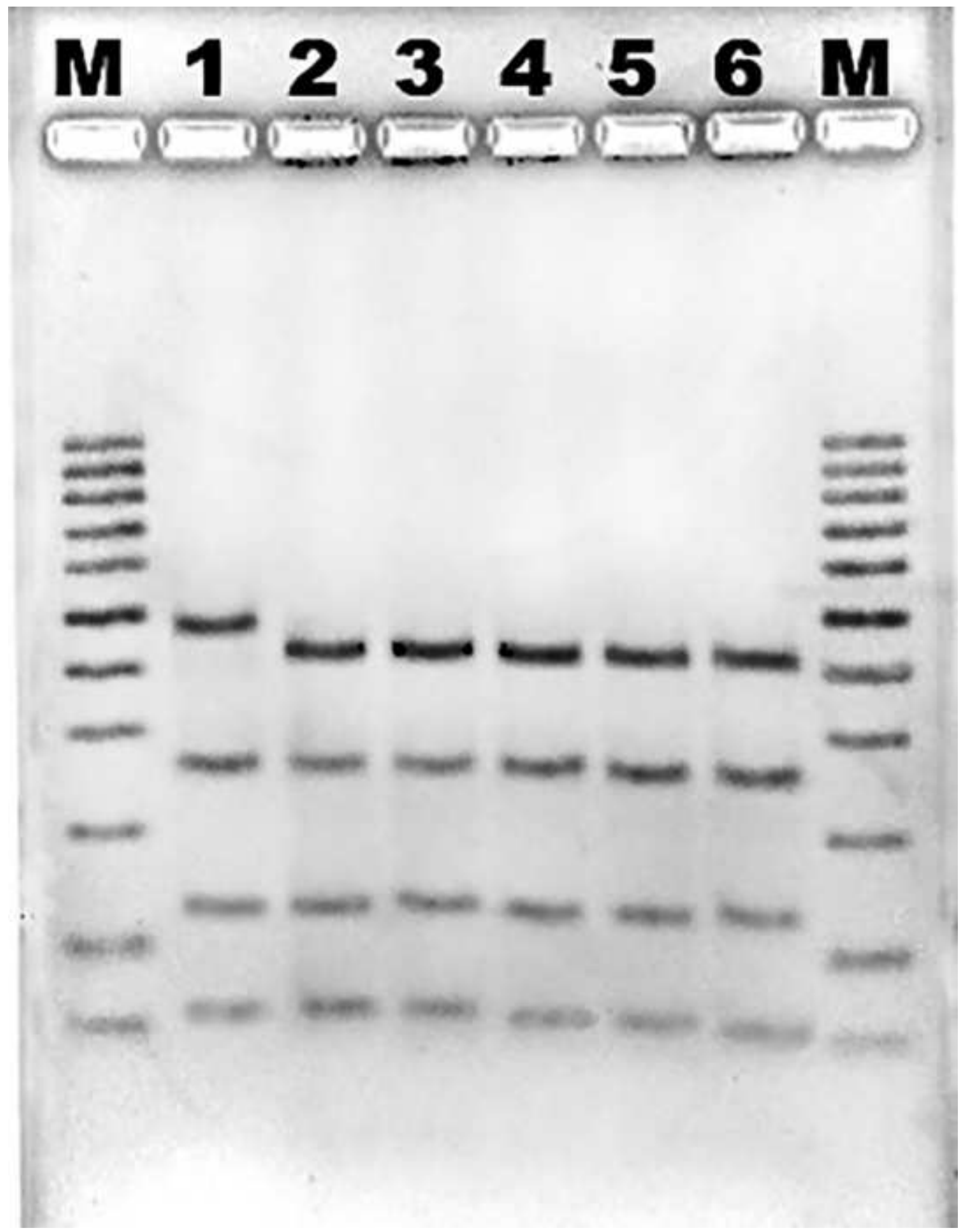


Dear Sir,

We are thankful to reviewers for benevolent and positive replies, useful comments and corrections. We made all grammar and stylistic corrections suggested by reviewers.

\section{Reply to Reviewer 1}

According to the recommendation of Reviewer, we introduced to the section 2 (Materials and methods) a description of the film stability control: "Radioactivity of the films remained unchanged after a two-week period of incubation in water which ensures that tritium does not move to the aqueous bacteria suspension in the course of the experiments.

\section{Reply to Reviewer 2}

1 line: Corrected for: "The mechanism of biological activation by betaemitting radionuclide tritium was studied in the paper."

9 line: Corrected for: "An activation of the intracellular bioluminescence process can take place without penetration of tritium atoms into the cells and can be the result of intensification of trans-membrane cellular processes stimulated by ionization and radiolysis of aqueous media."

\section{Reply to Guest Editor:}

The text was corrected, English improved.

Highlights: The first highlight was changed.

The order of reference was changed starting from the oldest ones.

"Radioactivity" or "specific radioactivity" was changed to "activity concentration".

Phrase "Tritium, a soft beta-emitting radionuclide without accompanying gamma-rays..." was introduced.

First paragraph was transferred from Conclusions to Introduction with minor changes.

List of references was corrected, numbers were removed.

Fig. 1 was removed.

Lines in Fig. 3 were made sharper. 